\title{
Community College: Expectation and Reality
}

\author{
Sunaryo Soenarto \\ Universitas Negeri Yogyakarta \\ Yogyakarta, Indonesia \\ sunaryos@uny.ac.id
}

\begin{abstract}
Law no. 12 Year 2012 on Higher Education provides formal legality for Community College as one form of higher Education, which organizes vocational education at Diploma Level 1 (D1) or Diploma Level 2 (D2) in one or several branches of particular science or technology by concerning on local excellence to meet a special need. In the early stages of 2012, 35 Community Colleges were developed through the study programs outside of the domicile. The early development of Community College aims at increasing the potential of its region, the ability of senior high school graduates to be self-sufficient as well as expanding the access to higher education and improving college GER (Gross Enrollment Rate). Local people and the public expect that the Community College is able to motivate the society and the high school graduates community to be an alternative choice of education.
\end{abstract}

Keywords-community college

\section{INTRODUCTION}

The Agreement of ASEAN Economic Community (AEC) provides wide opportunity for foreigners to have carrier in all ASEAN member country where it creates a tight labor competition. It makes competence or expertise becomes the main barometer to seize the chance among other ASEAN workers. Since the high competent and relevant worker will have a wider opportunity to get a job and to obtain economic benefits. However, without an adequate competence, the young generation of Indonesian will be set aside in the regional job competition even in their own country.

The productive and applied human resources are the key factor for regional and national economic growth of Indonesia. Then, in order to produce a productive and applied labor, a qualitied education as well as relevant to the local development needs is required. The paradigm has shiftyed from the social needs economy toward a knowledge-based economy and technology. Indonesian human resources are expected to be more capable of applying science and technology (especially information and communications technology), so that Indonesian workers become more valueadded to seize domestic and even regional job market opportunities. To create a expert competence, productive, innovative, and skillfull workforce, the role of higher education is very important to prepare Indonesian human resources to compete with foreign workers.

The goal of Community College establishment is also to increase GER (Gross Enrollment Rate) score of Higher Education In 2010-2014. The target is 40\%, but the realization is only $29.15 \%$ (Ristekdikti, 2016) [1]

\section{RESULT AND DISCUSSION}

\section{A. Community College}

Community College is a place to gain valuable knowledge (knowledge, technical and vocational skills) that society and entrepreneurs need (Emeagwali, 2007) [2]. Broader understanding is delivered by Jacobs and Grubb (2003)[3], that Community College is a higher education to form basic skills, vocational and to produce certain skilled workers. Community College in the United States is known as "two-year college" or "Junior College", to serve the society around toll roads and public transportation routes so theycan reach campus easily. The offered programs are a transfer to university, Technical programs, job training programs, basic skills programs, and specialization programs.

Malaysia has been developing Community College since 2001 , with the primary goal of providing alternative skills training and education for secondary school graduates, as well as for citizens who have abandoned the formal education system. In Malaysia, the purpose of Community College is to provide the certificates and credential to students who (academically) may not be able to compete for local universities, or for those who have failed to obtain other higher education institutions. Community College offers programs that emphasize hand-on and practical in the community. The course lecture ratio for theory and practice si between $75 \%: 25 \%$. Community College Malaysia offers several programs, including: automotive engineers, electrical technicians, computer technicians, catering, fashion, food processing and quality control. In the structure of the Ministry of Higher Education in Malaysia, Community College is coordinated by positions of Polytechnic and Community College. The Ministry of Technology and Higher Education needs to learn from Malaysia in case of developing Community College where within fifteen years, there were 115 Community Colleges had been built by state universities. Even 115 Community Colleges have been accredited by the Public Service Department (PSD) [4].

The perceptions of Community College students in Malaysia align with a series of statements that community colleges provide an opportunity to build and develop their future. It is reinforced by Barabasch (2006) in his qualitative research which found that Community College students feel their skills training at colleges can help them to understand a quality work for their future. The findings of this study 
showed the similar result and provide more opportunities for better learning quality (Ahmad et. al., 2009) [5].

Law No. 12 of 2012, article 59, explains the Community Academy is one form of higher education. Article 81 (paragraphs 1 and 2) in detail clarifies that the central government together with the regional government shall gradually develop at least 1 (one) community college which consistent with the region potential in border areas. The community collefe is implemented based on local needs to accelerate the progress and welfare of the community. Referring to the blueprint of the Community College Establishment Guidelines (2013), the Community College is a university which conduct vocational education at the D-1 or D-2 level in one or several branches of particular science or technology by concerning on local excellence to meet a special need.

It is predicted that the establishment of Community Academy throughout Indonesia until the year 2015 was 269. The opening of courses at the Community College is aligned with economic corridors, so it is expected to open up new economic centers. The distribution of 269 Community College presented in figure 1 below.

It is estimated by 2015, Community Academy will have a total of 24,210 students by assuming that each Community College has at least 3 courses (which have local advantages) with a total of 30 students per courseroughhe prediction is developed with the assumption that every polytechnic develop it and mantain a study program outside the higher education domicile. The implementation of the Community College under the guidance of the master university through PDD (Program Diluar Domisili/ Outside Domicile Program) should be supported by the local government of the regency/ city, as defined in the Regulation of the Minister of National Education of Indonesia No. 20 of 2011. The main work agenda of the minister (June 2011) that, in 2025, it will be built 824 Community Academy and there will be 74,160 students of Community College.

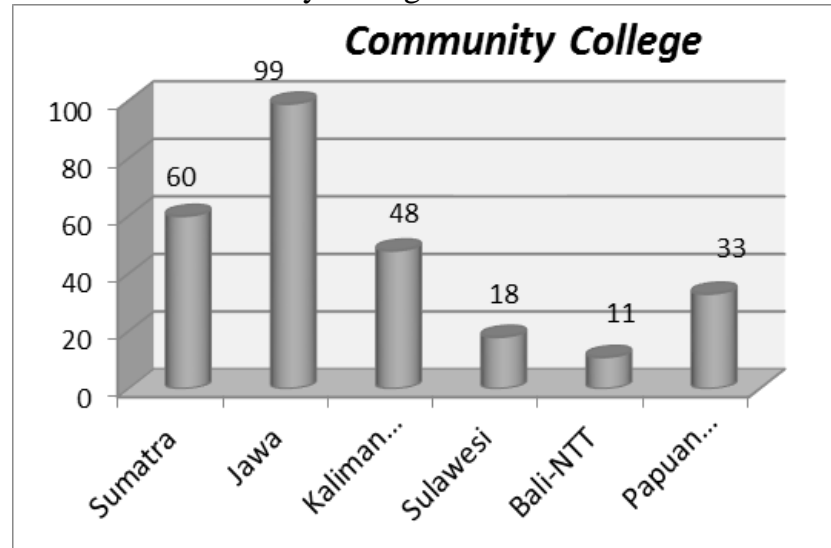

Figure. 1 The distribution of Community College establishment [6]

The Community College curriculum is developed by synergetically among academic community of polytechnic/ college, industrial society / business world and professional organizations. The graduates of the Community College are ready to use as an actos at the economic growth centers of every economic corridor. As a Diploma provider according to the potential of the region, its existence in every city / district throughout Indonesia should be the main consideration. The formulation of the Community Academy curriculum is aligned with the vocational higher education curriculum. The curriculum defines each level held competency-based with a certain competency achievement. The achievement of these competencies refers to the profile of graduates of the study programs in the business or industry based on local excellence of each region.

At the beginning of the twenty-sixth Community College establishment in 2012, the curriculum refered to the Ministerial Decree No. 045 / U / 2002, that the curriculum encompasses major competencies, supportting competencies, and other specialized competencies. By the time, the community college curriculum is arranged according to Presidential Regulation No. 8/2012 on the Indonesian National Qualification Framework. The standard of competences were adjusted to the Indonesian National Qualification Framework. Academic Curriculum refers to vocational education of Diploma level 1 (D-1) and Diploma level 2 (D-2) whichn consisted of 3 competencies, namely: general competence, skill competency, and special competence. For general competence students were expected to have: (a) ability to communicate in foreign languages and Indonesian well, (b) ability to utilize basic IT, so that students can access internet, and (c) ablity to implement industrial ethics of working safety, communicating / interacting with supervisor and fellow staff. The learning management strategy was designed with preferential work skills with composition of $30-40 \%$ for theory, and $60-70 \%$ for practice (including industrial work). The graduates of the Community College were expected to obtain competency certification in accordance with the needs of employment, or may pursue to the appropriate higher education level. The structure of the Community College curriculum presented below.

TABLE 1. Composition of Community College curriculum[7]

\begin{tabular}{|l|l|l|l|l|}
\hline Competence & Course & D2 & D1 & $\begin{array}{l}\text { Competency } \\
\text { certification }\end{array}$ \\
\hline General & MKU & 8 & 4 & -- \\
\hline Expertise & $\begin{array}{l}\text { MK } \\
\text { Expertise }\end{array}$ & 60 & 30 & 15 \\
\hline Specfic & $\begin{array}{l}\text { MK } \\
\text { Specific }\end{array}$ & 4 & 2 & --- \\
\hline Total & & 72 & 36 & 15 \\
\hline
\end{tabular}

General course include:

1. Communication ability

2. ICT Utilization skill

3. Industrial ethnic implementation

B. Community College Contribution Toward GER (Gross Enrollment Rate) 
Minister of Research, Technology and Higher Education, Mohamad Nasir in the 1-year Reflection agenda said that in 2015, various targets have been achieved. One of them is the high Gross Enrollment Rate (GER) in 2015 of 33.5 percent, above the initial target of the year i.e. 26.8 percent. ${ }^{1)}$ However, achievement of GER colleges in 2015 was still lower than the target, i.e. 35 percent. As quoted in Republika that the Minister of Education and Culture, Muhammad Nuh, explained in 2015, GER of education was targeted to reach 35 percent. In 2013, GER of higher education only reached 29 percent. While in 2014, it was expected that high education GER reached 30 percent. This number was increase 12 percent in the last four years. Previously, the GER in 2009 was only 18 percent. 2) The GER of developed countries reached 40 percent. Target and Achievement of higher education participation rate of the Ministry of Education and Culture in 2010-2014 can be presented following radar diagram.

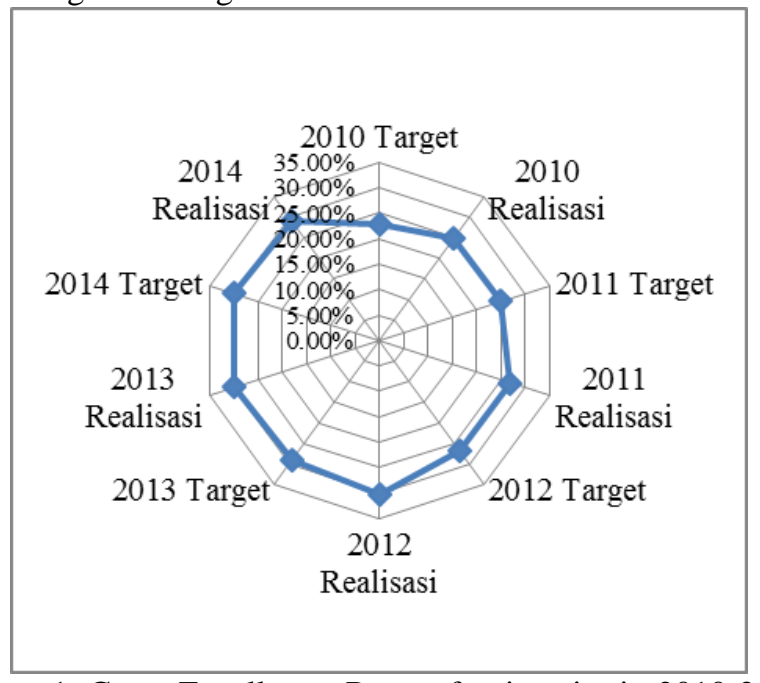

Figure 1. Gross Enrollment Rate of university in 2010-2014 [8]

Up to this point, the central and local governments synergically encourage various human resources development programs that are oriented to excellence and potential according to the regional corridor through the Community College. In the Strategic Plan of Kemendikbud in the year 2010-2014 expressly States that the increased access to higher Education were conducted by several activities such as establishing a new college, private colleges acquisition, and the establishment of the Community College. However, in the National Medium-Term Development Plan 2015-2019, the direction of the policy relating to higher education for improvement and equitable access of higher education through capacity building strategies and equitable access to higher education did not explicitly relate to the establishment of the Community College. It means two period of higher education policies, the strategic program on Community College has been reduced.

\section{The REALITY OF COMMUNITY COLLEGE}

This article is based on secondary data analysis available at http://akademikomunitas.ristekdikti.go.id/ from May 2016 to July 2017. The website is managed by Directorate General of Learning and Student Affairs, Ministry of Research, Technology and Higher Education. Based on the analysis of the Community College database at http://akademikomunitas.ristekdikti.go.id/ the number of Community College in the Ministry of Research, Technology and Higher Education were 92. The number of Community College per 2017 only reached 34.2 percent than the initial prediction was 269. The Ninety-two Academy Community has 25 Diploma I (D1) courses, and 152 Diploma II courses (D2). The Seventeen Pilots of the new Community Collge had no students enrolled in the Ristekdikti database, such as the State Community College: D.I. Yogyakarta, Coal Regency, Demak, Central Halmahera, Jembrana, Hedgehog,. Sabu Raijua, Bitung City, Cimahi City, Sibolga Town, Banggai Islands, Bulungan, Mentawai Islands,. Selayar Islands, Lumajang, Pidie Jaya, and Sorong Selatan. After the separation between the Ministry of Education \& Culture and the Ministry of Research, Technology and Higher Education in 2014, the establishment of the Community Academy found some obstacles and became slowdown, it was proven in 2016 and 2017 there was no new establishment of Community College. Even the issue of the establishment of the Community Academy does not explicitly become a main goal in the Strategic Plan of Ministry of Research, Technology and Higher Education in 2015-2019. In 2017, the issues and information about the Community College program are not as intensive as in 2013-2014. Even in 2017, the news or information in internet about the establishment or opening of Community College cannot be easily obtained.

The impact of the lack of socialization and promotion of Community Academy, the interest and acceptance of new students in 2016 drop dramatically. Since the establishment of the Community Academy of 2012 to 2014, the number of students has increased significantly. In the first year (2012), the Community College received 2,388 new students, male students of 1,591 people, 797 for women. Two years later (2014), the Community Academy accepted almost twice than the first year, totaling 5,669 students. But the irony, two years later (2016) the number of new students at the Community Academy drop sharply into 818 students. Compared to the previous two years, the number of new students was only $14.4 \%$. The new student admission data, in detail, from 2012-2016 was presented in below. 
TABLE 1. the students number of Community College in 2012 - 2016 [9]

\begin{tabular}{|l|l|l|l|l|l|l|}
\hline Enrollment year & $\mathbf{2 0 1 2}$ & $\mathbf{2 0 1 3}$ & $\mathbf{2 0 1 4}$ & $\mathbf{2 0 1 5}$ & $\mathbf{2 0 1 6}$ & Total \\
\hline Male & 1.591 & 3.622 & 3.569 & 2.341 & 472 & 11.595 \\
\hline Femal & 797 & 2.051 & 2.100 & 1.389 & 346 & 6.683 \\
\hline The students number per year & 2.388 & 5.673 & 5.669 & 3.730 & 818 & 18.278 \\
\hline
\end{tabular}

On the other hand the of human resources for Community College, the lecturer (instructor) and educational staff is sufficient. They consists of lecturers, and instructors. The lecturers status are Civil Servants (PNS), non civil servants, permanent and non-permanent. Lecturers are professional educators and scientists with the primary task of transforming, developing and disseminating science and technology through Education, research and community Service. Instructors are functional personnel to assist lecturers in guiding and giving students training in practical activities in workshops, or laboratories. The instructor staff consists of skilled level instructors and expert level instructors. Lecturers in 92 Community College amounted to 807 persons with the details status as follows (a) lecturers of civil servants of the Ministry of Education and Culture about 214 persons, (b) civil servant of local government was 175 people, and (c) 428 lecturers of non-civil servants. The number of instructors who assisted practical learning and field practice amounted to 491 people consisting of (a) civil servant instructor of Ministry of Education and Culture as many as 84 people, (b) civil servant of local government as many as people, and (c) non-civil servants as many as 317 people. Meanwhile, the number of educational staffs of administration, academic administration, laboratory and cleaning personnel as many as 485 people, which consist of civil servant of Ministry of Education and Culture as many as 23 people, local government civil servants as many as 101 people, and 361 non-civil servants. Graphically, it can be presented as follows.

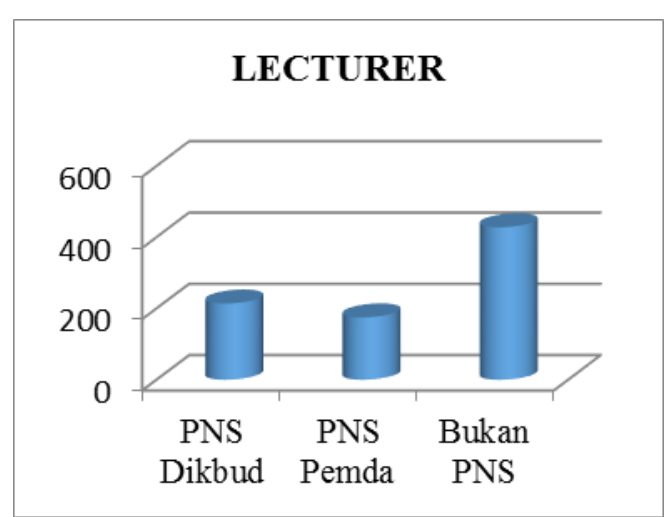

Figure 2 Lecturer Data in 92 CC [9]

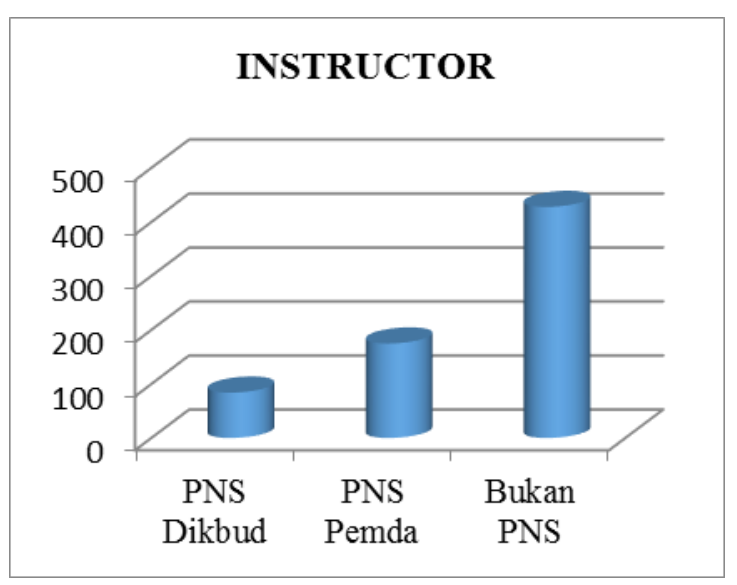

Figure 3. Instruktur data in 92 CC [9]

Based on the study, 92 Community College had been able to accommodate 17,506 graduates from senior high school/vocational/madrasah, this will surely increase GER of universities. If the Strategic Plan of the Ministry of Research, Technology and Higher Education in 2014-209 can strengthen the Strategic Plan of the Ministry of Education and Culture in 2010-2014, by placing the programs to improve the relevance of education and increase the access and the target with Community College as many as 269 in all districts/ cities of Indonesia into the priority. The Assumption, at that time, each Community College has 4 courses (D1 and D2), and each course has 30 students, then Community College every year will be able to accommodate 32,280 people. Thus, the strategic target of 2019 as the target of the Ministry of Research, Technology and Higher Education with the indicator GER increase from $29.15 \%$ in 2014 to $32.56 \%$ in 2019, can be easily realized.

\section{CONCLUSION}

Pilot Program of the Ministry of Education and Culture in 2010-2014 has received attention and strategic programs at the government level of district/ city throughout Indonesia. They had responden by providing land for the campus building. Meanwhile, the Directorate General of Higher Education (at that time) regularly rolled out funds to develop educational and learning programs as much as 50 billion rupiah for the construction of the state community college Campus and it is very potential because of a high increase number of inhabitants entering the college age. However, unfortunately, the guidance, the targets and the government programs are inconsistent that makes the number of new students in 2016 
dropped dramatically, only 818 people. With the declining number of the students, the availability of human resources lecturers, instructors and educational personnel are not optimally empowered.

\section{REFERENCES}

[1] Ristekdikti. 2016. http://ristekdikti.go.id/refleksi-1-tahunkementerian-riset-teknologi-dan-pendidikan-tinggi, diakses 12 Mei 2016

[2] Emeagwali, N.S. (2007). Community College Offer Baby Boomers and Encore. [Online] Available:http://www.acteonline.org (March 17, 2007).

[3] Jacob \& Grubb. (2003) http://www.americancommunitycolleges.comisgarticles/c ommunitycollege-stepping stone.php), diakses 20 Februari 2016

[4] Public Service Department. http://www.studyadvisor.com.my/ communitycolleges.htm.).diakses 21 Februari 2016
[5]Ahmad Esa, Abdul Rasid, \& Abdul Razzaq (2009), The Perception of Students towards the Community Colleges' Courses That Offered in Malaysia, Asean Social Science Vol. 5, No 7, July, 2009)

[6][7]Direktur Kelembagaan dan Kerjasama (2013). Cetak Biru Akademi Komunitas, Direktorat Kelembagaan dan Kerjasama, Direktorat Jendral Pendidikan Tinggi, Kementerian Pendidikan dan Kebudayaan.

[8] http://ristekdikti.go.id/refleksi-1-tahun-kementerian-risetteknologi-dan-pendidikan-tinggi, diakses 2 Januari 2016.

[9] http://akademikomunitas.ristekdikti.go.id/akademi/index, diunduh Juli 2017

[10] Sunaryo Soenarto. 2016. Strengthening Community College to Improve GrossEnrolment Ratio (Ger) of Higher Education. procceding Strengthening TVET in ASEAN Economic Community at September 15, 2016. Yogyakarta: Yogyakarta State University. 